\title{
Removal of Heavy Metal Ions from Wastewater by Chemically Modified Agricultural Waste Material as Potential Adsorbent-A Review
}

\author{
Jyotikusum Acharya ${ }^{\#^{\wedge}}$, Upendra Kumar^ and P. Mahammed Rafi ${ }^{\#^{*}}$ \\ \#Department of Civil Engineering, Mallareddy Institute of Technology and Sciences, Hyderabad, India \\ ${ }^{\wedge}$ Department of Civil Engineering, National Institute of Technology, Silchar, Assam, India
}

Received 05 March 2018, Accepted 08 May 2018, Available online 11 May 2018, Vol.8, No.3 (May/June 2018)

\begin{abstract}
Heavy metal remediation of aqueous streams is of special concern due to recalcitrant and persistency of heavy metals in environment. Conventional treatment technologies for the removal of these toxic heavy metals are not economical and further generate huge quantity of toxic chemical sludge. Agricultural waste materials being economic and ecofriendly due to their unique biochemical composition, availability in abundance, renewable, low in cost and more efficient are seem to be viable option for heavy metal remediation. The major advantages of biosorption over conventional treatment methods include: low cost, high efficiency, minimization of chemical or biological sludge, regeneration of biosorbents and possibility of metal recovery. It is well known that cellulosic waste materials can be obtained and employed as cheap adsorbents and their performance to remove heavy metal ions can be affected upon chemical treatment. In general, chemically modified plant wastes exhibit higher adsorption capacities than unmodified forms. The functional groups present in agricultural waste biomass viz. acetamido, alcoholic, carbonyl, phenolic, amido, amino, sulphydryl groups etc. Have affinity for heavy metal ions to form metal complexes or chelates. Some of the treated adsorbents show good adsorption capacities for $\mathrm{Cd}, \mathrm{Cu}, \mathrm{Pb}, \mathrm{Zn}$ and Ni. Rice husk as a low-value agricultural by-product can be made into sorbent materials which are used in heavy metal removal. The mechanism of biosorption process includes chemisorptions, complexation, adsorption on surface, diffusion through pores and ion exchange etc. Agricultural residues are lignocelluloses substances which contain three main structural components: hemicelluloses, cellulose and lignin. Lignocellulosic materials also contain extractives. Generally, three main components have high molecular weights and contribute much mass, while the extractives is of small molecular size, and available in little quantity, which announce in heavy metal removal.
\end{abstract}

Keywords: Agricultural waste material; Heavy metals; Adsorption; Wastewater treatment

\section{Introduction}

Heavy metals constitute a very heterogeneous group of elements widely varied in their chemical properties and biological functions. The term heavy metals defined as commonly held for those metals, which have specific weights more than $5 \mathrm{~g} \mathrm{~cm}^{-3}$ (Holleman and Wiberg et al, 1985). Heavy metals can enter a water supply by industrial and consumer waste, or even from acidic rain breaking down soils and releasing heavy metals into streams, lakes, rivers, and groundwater. Some of the heavy metals i.e. arsenic (As), Cadmium $(\mathrm{Cd})$, Lead $(\mathrm{Pb})$, Mercury $(\mathrm{Hg})$ are cumulative poison. The high concentration intake of cadmium cause itai itai disease and mercury intake lead to minamita disease and other heavy metals cause poisoning due to drinking water contamination. The contamination of water due to toxic heavy metal ions is accountable for

*Corresponding author's ORCID ID: 0000-0001-8284-081X DOI: https://doi.org/10.14741/ijcet/v.8.3.6 causing several damages to the environment and adverse effects on the health of the people like mental retardation, reduction in hemoglobin production and interference with normal cellular metabolism and consequently may damage nervous system.

Strong exposure may cause gastric pain, nausea, vomiting, severe diarrhea, hemorrhage and even cancer in the digestive tract and lungs. Metals and other poisons like chemicals, mold toxins and the toxic waste from bacteria and other parasites are fat soluble. They dissolve in and move through fat. If they gain entrance to the body they end up in the cell walls. Residing in the fat, they cause some of the fat to change shape. The new fats are too long, have the wrong connections between elements or have a funny shape or all of the above. They are square pegs trying to fit into round holes. The new shapes change the ability of the fats to fit into the anatomy of the cell or function in the action steps or physiology necessary to sustain cell life. So the action or physiology of the body is slowed down and illness results or the action stops and death 
results. Results of studies on the adverse effects on human health have been summarized in numerous reports published by international organizations, e.g. the World Health Organization (WHO) and the International Agency for Research on Cancer (IARC), or governmental agencies such as the Centers for Disease Control and Prevention (CDC) in the United States.

The presence of heavy metals in waste and surface waters is becoming a severe environmental problem and because of their non-biodegradability, they can accumulate in the food chain posing a significant danger to human health. The main techniques, which have been utilized to reduce the heavy metal ion content of effluents, include lime precipitation, ion exchange, adsorption into activated carbon, membrane process and electrolytic methods. All these methods are generally expensive (Kumar and Bandyopadhyay et al, 2006) . Recently, agricultural waste materials have been proposed as economic and eco-friendly adsorbents (D. Sud et al, 2008) . Agricultural materials, particularly those containing cellulose, show a high potential in metal biosorption capacity (D. Ranjan et al, 2009) . Adsorption process of heavy metals present in aqueous solution by low-cost adsorbents from plant wastes can be carried out with or without chemical modifications. In general, chemically modified plant wastes exhibit higher adsorption capacities than unmodified forms (W. S. WanNgah et al, 2008 ). Living as well as dead (metabolically inactive) biological materials have been sought to remove metal ions. It was found that various functional groups present on their cell wall offer certain forces of attractions for the metal ions and provide a high efficiency for their removal (R. Ashkenazy et.al 1995-97; N. Kuyucak, and B. Volesky et al,1988).

Some methods to remove metal ions from Wastewaters

\begin{tabular}{|c|c|c|}
\hline Methods & Advantages & Disadvantages \\
\hline Chemical Precipitation & $\begin{array}{c}\bullet \quad \text { Simple } \\
\bullet \quad \text { Inexpensive } \\
\bullet \quad \text { Most of metals can be removed }\end{array}$ & $\begin{array}{l}\text { - Large amounts of sludge produced } \\
\text { • Disposal problems }\end{array}$ \\
\hline Chemical coagulation & $\begin{array}{cc}\bullet & \text { Sludge settling } \\
\bullet & \text { Dewatering } \\
\end{array}$ & $\begin{array}{c}\bullet \text { High cost } \\
\text { - Large consumption of chemicals }\end{array}$ \\
\hline Ion-exchange & $\begin{array}{c}\text { - High regeneration of materials } \\
\bullet \quad \text { Metal selective }\end{array}$ & $\begin{array}{c}\bullet \text { High cost } \\
\text { - Less number of metal ions removed }\end{array}$ \\
\hline Electrochemical method & $\begin{array}{c}\text { - Metal selective } \\
\text { - } \quad \text { No consumption of chemicals } \\
\text { - } \quad \text { Pure metals can be achieved } \\
\end{array}$ & $\begin{array}{c}\text { • High capital cost } \\
\bullet \text { High running cost } \\
\text { - Initial solution pH and Current density }\end{array}$ \\
\hline $\begin{array}{c}\text { Adsorption } \\
\text { Using activated carbon }\end{array}$ & $\begin{array}{l}\text { - Most of metals can be removed } \\
\text { - High efficiency }(>99 \%)\end{array}$ & $\begin{array}{c}\text { • Cost of activated carbon } \\
\bullet \text { No regeneration } \\
\text { - Performance depends upon adsorbent }\end{array}$ \\
\hline Using natural zeolite & $\begin{array}{l}\text { - } \text { Most of metals can be removed } \\
\text { - } \quad \text { Relatively less costly materials }\end{array}$ & - Low efficiency \\
\hline $\begin{array}{c}\text { Membrane process and } \\
\text { ultrafilteration }\end{array}$ & $\begin{array}{l}\text { - Less solid waste produced } \\
\text { - Less chemical consumption } \\
\text { - High efficiency (>95\% for single metal) }\end{array}$ & $\begin{array}{c}\text { - High initial and running cost } \\
\text { - Low flow rates } \\
\text { - Removal (\%) decreases with the } \\
\text { presence of other metals }\end{array}$ \\
\hline
\end{tabular}

Source: (O'Connell et a,. 2008; Farooq et al, 2010)

\section{Low cost adsorbent wastes materials}

Biosorption is the removal of materials (compounds, metal ions, etc.) by inactive, non-living biomass (materials of biological origin) due to "high attractive forces present between the two (B. Volesky et al, 1995.) [9]. Several recent publications utilized different inexpensive and locally abundantly available adsorbents like barley straw (V. J. Larsen et al, 1981). waste tea leaves (T. W. Tee et al, 1981). sago waste( S. Y. Quek et al, 199). peanut hulls( P. Brown et al, 2000). hazel nut shell (G. Cimino et al, 2014 ). saw dust (A. Sukla et al, 2002; T. K. Naiya et al, 2008). neem bark (T. K. Naiya et al, 2008). chitin beads (D. Zhou et al, 2004), thermally treated rice husk ash (G. Doner, et al, 2004). waste banana (G. Annadurai et al, 2003). orange peels (G. Annadurai et al, 2003). cocoa shells (N. Meunier et al, 2003) tree fern (Y. S. Ho et al, 2004). coffee residue (V. Boonamnuayvitaya et al, 2004). rice husk( T. C. Chuah, et al, 2005 ; palm kernel fibre Y. S. Ho et al, 2005 ) , olive stone waste (N. Fiol et al, 2006), orange peel (Z. Xuan et al, 2006). grape stalk (M. Martinez et al, 2006). ( coir S. Y. Quek et al, 1998; K. Conrad et al, 2007). Tea waste (B. M. W. P. K. Amarasinghe et al, 2007), bagasse fly ash( V. K. Gupta et al, 2004; V. K. Gupta at al, 1998 ). rice husk (Q. Feng et al, 2004,) etc. Some of the advantages of using plant wastes for wastewater treatment include simple technique, requires little pro- cessing, good adsorption capacity, selective adsorption of heavy metal ions, low cost, free availability and easy regeneration.

\section{Chemically modified plant}

However, the application of untreated plant wastes as adsorbents can also bring several problems such as low adsorption capacity, high chemical oxygen demand (COD) and biological chemical demand (BOD) as well as total organic carbon (TOC) due to release of soluble organic compounds contained in the plant materials. Pretreatment of plant wastes can extract soluble organic compounds and enhance chelating efficiency 
[33]. Pretreatment methods using different kinds of modifying agents such as solutions sodium hydroxide, calcium hydroxide, sodium carbonate, Sulfuric acid, Thioglycollic acid, Hydrochloric acid, Tartaric acid, formaldehyde, epichlorohydrin etc, for the purpose of removing soluble organic compounds, eliminating colouration of the aqueous solutions and increasing efficiency of metal adsorption have been performed by many researchers.

Dubey and Gopal et al,2006; Abia et al, 2006; 0" zer et al. 2004; 0" zer and C. Pirince et al, 2006; Min et al, 2004; Shukla and Pai et al, 2005a; Low et al. 2000; Chubar et al. 2004; Memon et al, 2007; Bulut and Tez et al, 2003; Shukla and Pai et al, 2005b; Argun et al,2007; Hanafiah et al, 2006a; Ganji et al , 2005; Pehlivan et al., 2006; Gupta and Ali et al., 2004; Wankasi et al, 2006; Mohanty et al., 2005; Wong et al., 2003b; Kumar and Bandyopadhayay et al., 2006, Bansal et al., 2009; J. Cruz-Olivaresa et al., 2010; The types of chemicals used for modifying plant wastes and their maximum adsorption capacities are shown in Table 1. Pretreatment of rice husks can remove lignin, hemicellulose, reduce cellulose crystallinity and increase the porosity or surface area. Cellulose is a crystalline homo-polymer of glucose with $ß \rightarrow 4$ glycosidic linkage and intra-molecular and intermolecular hydrogen bonds.

Summary of modified plant wastes as adsorbents for the removal of heavy metal ions from aqueous solution

\begin{tabular}{|c|c|c|c|c|}
\hline Adsorbent & Modifying agent(s) & Heavy metal & Qmax (mg/g) & Source \\
\hline Groundnut husk & Sulfuric acid followed by silver & $\mathrm{Cr}(\mathrm{VI})$ & 11.4 & (Dubey and Gopal et al.,2006) \\
\hline Cassava waste & Thioglycollic acid & $\mathrm{Cd}(\mathrm{II})$ & NA & (Abia et al, 2006). \\
\hline Wheat bran & Sulfuric acid & $\mathrm{Cu}(\mathrm{II})$ & 51.5 & (Ozer et al, 2004). \\
\hline Wheat bran & Sulfuric acid & $\mathrm{Cd}(\mathrm{II})$ & 101 & (Ozer and Pirinc et al, 2006). \\
\hline Juniper fibre & Sodium hydroxide & $\mathrm{Cd}(\mathrm{II})$ & 29.54 & (Min et al, 2004). \\
\hline $\begin{array}{l}\text { Indian barks } \\
\text { Sal,mango, jackfruit }\end{array}$ & Hydrochloric acid & $\mathrm{Cu}(\mathrm{II})$ & $\begin{array}{l}51.4 \\
42.6 \\
17.4\end{array}$ & (Shukla and Pai et al, 2005a). \\
\hline Spent grain & Hydrochloric acid & $\mathrm{Cd}(\mathrm{II})$ & 17.3 & (Low et al., 2000). \\
\hline Cork powder & $\begin{array}{l}\text { Calcium chloride, Sodium chloride } \\
\text { Sodium hydroxide } \\
\text { Sodium iodate }\end{array}$ & $\mathrm{Cu}(\mathrm{II})$ & $\begin{array}{l}15.6 \\
18.8 \\
18.0 \\
19.0\end{array}$ & (Chubar et al,2004). \\
\hline $\begin{array}{l}\text { Sawdust (cedrus } \\
\text { deodar wood) }\end{array}$ & Sodium hydroxide & $\mathrm{Cd}(\mathrm{II})$ & 73.62 & (Memon et al, 2007). \\
\hline Walnut sawdust & Formaldehyde in sulfuric acid & $\mathrm{Pb}(\mathrm{II})$ & 4.48 & (Bulut and Tez et al., 2003). \\
\hline Sawdust & Reactive Orange 13 & $\begin{array}{l}\mathrm{Cu}(\mathrm{II}),(\mathrm{Ni}(\mathrm{II}) \\
\mathrm{Cr}(\mathrm{VI})\end{array}$ & 8.07 & (Shukla and Pai et al., 2005b). \\
\hline Sawdust (Oak tree) & Hydrochloric acid & $\mathrm{Pb}(\mathrm{II})$ & $\begin{array}{l}3.60 \\
3.37 \\
1.74 \\
\end{array}$ & (Argun et al, 2007). \\
\hline $\begin{array}{c}\text { Imperata cylindrica } \\
\text { leaf powder }\end{array}$ & Sodium hydroxide & $\mathrm{Cu}(\mathrm{II})$ & 13.50 & (Hanafiah et al, 2006a). \\
\hline $\begin{array}{l}\text { Azolla filiculoides } \\
\text { (aquatic fern) }\end{array}$ & $\begin{array}{c}\text { Hydrogen peroxide-Magnesium } \\
\text { Chloride }\end{array}$ & $\mathrm{Cu}(\mathrm{II})$ & 62 & (Ganji et al, 2005). \\
\hline Sugarbeet pulp & Hydrochloric acid & $\mathrm{Pb}(\mathrm{II})$ & 0.15 & (Pehlivan et al, 2006). \\
\hline Bagasse fly ash & Hydrogen peroxide & $\mathrm{Pb}(\mathrm{II}) \mathrm{Cu}(\mathrm{II})$ & 2.50 & (Gupta and Ali et al, 2004). \\
\hline $\begin{array}{c}\text { Nipah palm shoot } \\
\text { biomass }\end{array}$ & Mercaptoacetic acid & $\mathrm{Cu}(\mathrm{II})$ & $52.86,66.71$ & (Wankasi et al, 2006). \\
\hline $\begin{array}{c}\text { Terminalia arjuna } \\
\text { nuts }\end{array}$ & $\mathrm{ZnCl}_{2}$ & $\mathrm{Cu}(\mathrm{II})$ & 28.43 & (Mohanty et al, 2005). \\
\hline Rice husk & Tartaric acid & $\mathrm{Cd}(\mathrm{II})$ & 31.85 & (Wong et al, 2003b). \\
\hline Rice husk & $\begin{array}{c}\text { Water washed } \\
\text { Sodium hydroxide } \\
\text { Sodium bicarbonate } \\
\text { Epichlorohydrin }\end{array}$ & $\mathrm{Cd}(\mathrm{II})$ & $\begin{array}{c}8.58 \\
20.24 \\
16.18 \\
11.12 \\
\end{array}$ & (Kumar et al, 2006). \\
\hline Rice husk & BRH. FRH & lead(II) & $8.5,10.4$ & (M. Bansal et al, 2009). \\
\hline $\begin{array}{c}\text { De-Oiled Allspice } \\
\text { Husk }\end{array}$ & nitric acid, ethanol & lead(II) & $\begin{array}{c}20.07 \mathrm{mg} / \mathrm{gm}- \\
1(95 \%)\end{array}$ & (J. Cruz-Olivaresa et al, 2010 ). \\
\hline
\end{tabular}




\section{Rice husk as a novel adsorbent}

Rice husk was selected due to its local availability in abundance, chemical stability and insolubility in water (M. Akhtara et al, 2010). Rice which is cultivated in more than 75 countries in the world is the essential food for over half the world's population. The worldwide annual rice husk output is about 80 million tones and over $97 \%$ of the husk is generated in the developing countries (L. Armesto et al, 2002). Previous researches in the utilization of risk husk as novel adsorbents for different applications. The findings will provide a twofold advantage with respect to environmental management. First, large volume of rice husk waste could be partly reduced, converted to useful, value-added adsorbents, and second, the lowcost adsorbent, if developed, may overcome the wastewaters and air pollution at a reasonable cost, solving part of the global agricultural wastes and wastewater treatment problem. Developing countries; approximately 100 million tons of rice husk is available annually for utilization in these countries alone.

\section{Conclusion}

In this review the toxic metal ion biosorption on inexpensive and efficient biosorbents from agricultural waste materials have been investigated as replacement strategy for existing conventional systems. Agricultural waste material being highly efficient, low cost and renewable source of biomass can be exploited for heavy metal remediation. Chemical modification in general improved the adsorption capacity of adsorbents probably due to higher number of active binding sites after modification, better ion-exchange properties and formation of new functional groups that favours metal uptake. A wide range of low-cost adsorbents obtained from chemically modified plant wastes has been studied and most studies were focused on heavy metal ions such as $\mathrm{Cd}, \mathrm{Cu}, \mathrm{Pb}, \mathrm{Ni}$ and Cr(VI) ions (S. Chen et.al 1993).

\section{References}

Holleman, A. F. and E. Wiberg, (1985), Lehebuch du Anoranischen chemie. Water de Gruyter, Berlin, pp-868.

Kumar, U. and Bandyopadhyay, M. (2006), Sorption of cadmium from aqueous solution using pretreated rice husk, Bioresource Technology, vol. 97, pp. 104-107.

Sud, D. Mahajan, G. and Kaur, M. P. (2008), Agricultural waste material as potential adsorbent for sequestering heavy metal ions from aqueous solutions - A review, Bioresour. Technol. Vol. 99, pp. 6017-6027.

D. Ranjan, M. Talat, S. H. Hasan, (2009), Rice polish: an alternative to conventional adsorbents for treating arsenic bearing water by up-flow column method, Ind. Eng. Chem. Res., vol. 48 pp.10180-10185.

WanNgah, W.S. and Hanafiah, M. A. K. M. (2008), Removal of heavy metal ions from wastewater by chemically modified plant wastes as adsorbents: a review, Bioresour. Technol. Vol. 99 pp. 3935-3948

Ashkenazy, R. Gottlieb, L. and S. Yannai S. (1995-97), Characterization of acetone-washed yeast biomass functional groups involved in lead biosorption, Biotechnol. Bioeng. vol. 55, pp. 1-10.

Kuyucak, N. and Volesky, B. (1988), Biosorbents for recovery of metals from industrial solutions, Biotechnol. Lett. Vol.10, pp.137-142.

U. Farooq, U. A. Janusz, K. M. A. Khan, and M. Athar (2010), Biosorption of heavy metal ions using wheat based biosorbents - A review of the recent literature, Bioresource Technology, vol. 14 pp.5043- 5053.

B. Volesky, and Z. R. Holan (1995), Biosorption of heavy metals Biotechnol. Prog. vol. 11, pp. 235- 250.

V. J. Larsen, and H. H. Schierup, (1981), The use of straw for removal of heavy metals from wastewater, J. Environ Quart. vol. 10, pp. 188-19.

T. W. Tee, and A. R. M. Khan, (1988), Removal of lead, cadmium and zinc by waste tea leaves, Environ. Technol. Lett., vol. 9, pp.1223-1232.

S. Y. Quek, D. A. J. Wase, and C. F. Forster (1998), The use of sagowaste for the sorption of lead and copper, Water $S A$, vol. 24, pp. 251-256.

P. Brown, I. A. Jefcoat, D. Parrish, S. Gil, and E. Graham (2000), Evaluation of the adsorptive capacity of peanut hul pellets for heavy metals in solution, Adv. Environ. Res., vol. 4, pp. 19-29

G. Cimino, A. Passerini, and G. Toscano (2000), Removal of toxic cations and $\mathrm{Cr}(\mathrm{VI})$ from aqueous solution by hazelnut shell, Water Res., vol. 34 pp.2955-2962.

A. Sukla, Y. H. Zhang, P. Dubey, J. L. Margrave, and S. S. Sukla (2002), The role of saw dust in the removal of unwanted materials from water, J. Hazard. Mater., vol. 95, pp. 137152.

T. K. Naiya, A. K. Bhattacharya, and S. K. Das, (2008), Adsorption of $\mathrm{Pb}(\mathrm{II})$ by saw dust and neem bark from aqueous solutions, Env. Prog., doi:10.1002/ep.10280.

D. Zhou, L. Zhang, J. Zhou, and S. Guo (2004), Cellulose/chitin beads for adsorption of heavy metals in aqueous solution, Water Res., vol 38, pp. 2643-2650.

G. Doner, and S. Akman (2003), The removal of copper, cadmium and lead by rice husk ash, Fresen. Environ. Bull., vol.12, pp. 736-739.

G. Annadurai, R.S. Juang, and D. J. Lee (2003), Adsorption of heavy metals from water using banana and orange peels, Water Sci. Technol., vol. 47, pp 185-190.

N. Meunier (2003), Lead removal from acidic solutions by the sorption on cocoa shells: effect of some parameters, J Environ. Eng.,vol. pp 693-698.

Y. S. Ho, W. T. Chiu, C. S. Hsu, and C. T. Huang (2004), Sorption of lead ions from aqueous

solutions using tree fern as adsorbent, Hydrometallurgy, vol. 73, pp. 55-61.

V. Boonamnuayvitaya, C. Chaiya, W. Tanthapanichakoon, and S. Jarudilokkul (2004), Removal of heavy metals by adsorbent prepared from pyrolysed coffee residues and clay, Sep. Purif. Technol. Vol. 35, pp. 11-22.

T. C. Chuah, A. Jumasiah, I. Azni, S. Katayan, and S. Y. T. Choong (2005), Rice husk as a potentially low-cost bio sorbent for heavy metal and dye removal: an overview, Desalination, vol. 175, pp 305-316.

Y. S. Ho, and A. E. Ofomaj (2005), Kinetic and thermodynamics of lead ion sorption on palm kernel fibre from aqueous solution, Proc. Biochem. Vol. 40, pp. 34553461.

N. Fiol, I. Villaesscusa, M. Martinez, N. Miralles, J. Poch, and J. Serarols (2006), Sorption of $\mathrm{Pb}(\mathrm{II}), \mathrm{Ni}(\mathrm{II}), \mathrm{Cu}(\mathrm{II})$ and $\mathrm{Cd}(\mathrm{II})$ from aqueous solution by olive stone waste, Sep. Purif. Technol. Vol. 50, pp.132-140. 
Z. Xuan, Y. Tang, X. Li, Y. Liu, and F. Luo, (2006) Study on the equilibrium, kinetics and isotherm of biosorption of lead ions onto pretreated chemically modified orange peel, Bio. Eng. J. vol. 31, pp.160 164.

M. Martinez, N. Miralles, S. Hidalgo, N. Fiol, I. Villaeseasa, and J. Poch (2006), Removal of

lead (II) and cadmium (II) from aqueous solutions using grape stalk waste, J. Hazard. Mater. vol. 133, pp.203-211.

K. Conrad, and H. C. B. Hansen (2007), Sorption of zinc and lead on coir, Biores. Technol., vol. 98, pp 89-97.

B. M. W. P. K. Amarasinghe, and R. A. Williams (2007), Tea waste as a low cost adsorbent for the removal of $\mathrm{Cu}$ and $\mathrm{Pb}$ from wastewater, Chem. Eng. J., vol.132, pp. 299-309.

V. K. Gupta, and I. Ali (2004), Removal of lead and chromium from wastewater using bagasse fly ash- a sugar industry waste, J. Colloid Interf. Sci., vol. 271, pp. 321-328.

V. K. Gupta, D. Mohan, and S. Sharma (1998), Removal of lead from wastewater using bagasse fly ash-sugar industry waste material, Sep. Sci. Technol. Vol. 33, pp.1331-1343.

Q. Feng, Q. Lin, F. Gong, S. Sugita, and M. Shoya (2004), Adsorption of lead and mercury by rice husk, J. Colloid Interf. Sci., vol. 274, pp. 1-8.

I. Gaballah, D. Goy, E. Allain, G. Kilbertus, and J. Thauront (1997), Recovery of copper Through decontamination of synthetic solutions using modified barks Met. Metall. Trans. Vol. 28, pp. 13- 23.

A. Nakajima, and T. Sakaguchi (1990), Recovery and removal of uranium by using plant wastes, Biomass, vol. 21, pp. 5563.

S. P. Dubey, and K . Gopal (2006), Adsorption of chromium (VI) on low cost adsorbents derived from agricultural waste material: a comparative study. J. Hazard.Mater., doi:10.1016/j.jhazmat.2006.11.04.

A.A. Abia, O. B. Didi, and E. D. Asuquo (2006), Modelling of $\mathrm{Cd}^{2+}$ sorption kinetics from aqueous solutions onto some thiolated agricultural waste adsorbents, J. Appl. Sci. vol. 6, pp. 2549-2556.

A. Ozer, and D.Ozer (2004), The adsorption of copper(II) ions onto dehydrated wheat bran (DWB): determination of equilibrium and thermodynamic parameters, Process Biochem., vol. 39, pp.2183-2191, 2004.

A .Ozer, and H. B. Pirinc (2006), The adsorption of Cd(II) ions on sulfuric acid-treated wheat bran, J. Hazard. Mater. vol. 137, pp. 849-855.

S. H . Min, J. S. Han, E. W. Shin, and J. K. Park (2004), Improvement of cadmium ion removal by base treatment of juniper fiber, Water Res., vol. 38, pp. 1289-1295

S. R. Shukla, and R. S. Pai (2005), Adsorption of Cu(II), $\mathrm{Ni}(\mathrm{II})$ and $\mathrm{Zn}(\mathrm{II})$ on modified jute fibres, Bioresour. Technol, vol. 96, pp.1430-1438.

K. S. Low, C. K. Lee, and S. C. Liew (2000), Sorption of cadmium and lead from aqueous solutions by spent grain, Process Biochem., Vol. 36, pp. 59-64.

N. Chubar, J. R. Calvalho, and M. J. N. Correia (2004), Heavy metals biosorption on cork biomass: effect of the pretreatment. Colloids Surf., vol. 238, pp. 51-58.

S. Q. Memon, N. Memon, S.W. Shah, M.Y. Khuhawar, and M.I. Bhanger (2007), Sawdust - a green and economical sorbent for the removal of cadmium(II) ions.. Mater., vol. 139, pp. 116- 121.
Y. Bulut, and Z .Tez (2003), Removal of heavy metal ions by modified sawdust of walnut. Fresen. Environ. Bull, vol. 12, pp. 1499-1504.

S. R. Shukla, and R. S. Pai (2005), Adsorption of $\mathrm{Cu}(\mathrm{II})$, Ni(II) and $\mathrm{Zn}(\mathrm{II})$ on dye loaded groundnut shells and sawdust Sep. Purif. Technol. vol. 43, pp. 1-8.

M. E. Argun, S. Dursun, C. Ozdemir, and M. Karatas (2007), Heavy metal adsorption by modified oak sawdust: thermodynamics and kinetics. J. Hazard. Mater. Vol. 141, pp.77 - 85.

M. A. K. Hanafiah , S. C. Ibrahim, and M. Z. A. Yahya (2006), Equilibrium adsorption study of lead ions onto sodium hydroxide modified Lalang (Imperata cylindrica) leaf powder, J. Appl. Sci. Res.,vol. 2, pp. 1169-1174.

M. T. Ganji, M. Khosravi, and R. Rakhsaee (2005), Biosorption of $\mathrm{Pb}, \mathrm{Cd}, \mathrm{Cu}$ and $\mathrm{Zn}$ from wastewater by treated Azolla filiculoides with $\mathrm{H}_{2} \mathrm{O}_{2} / \mathrm{MgCl}_{2}$." Int. J. Environ. Sci. Technol. Vol. 1, pp. 265-271.

E. Pehlivan, S. Cetin, and B. H. Yanık (2000), Equilibrium studies for the sorption of zinc and copper from aqueous solutions using sugar beet pulp and fly ash J. Hazard. Mater., vol. 135, pp. 193-199.

D. Wankasi, M. Jr Horsfall, and A.I Spiff (2006), Sorption kinetics of $\mathrm{Pb} 2+$ and $\mathrm{Cu} 2+$ ions from aqueous solution by Nipah palm (Nypa fruticans Wurmb) shoot biomass, Elec. J. Biotechnol.Vol. 9, pp. 587-592.

K. Mohanty, M. Jha, B.C. Meikap, and M. N. Biswas (2005), Removal of chromium(VI) from dilute aqueous solutions by activated carbon developed from Terminalia arjuna nuts activated with zinc chloride, Chem. Eng. Sci., Vol. 60, pp. 3049-3059.

K. K. Wong, C. K. Lee, K. S. Low, and M. J. Haron (2003), Removal of $\mathrm{Cu}$ and $\mathrm{Pb}$ from electroplating wastewater using tartaric acid modified rice husk, Process Biochem, vol. 39, pp. 437-445.

M. Bansal , Umesh Garg, Diwan Singh, and V. K. Garg (2009), Removal of $\mathrm{Cr}(\mathrm{VI})$ from aqueous solutions using preconsumer processing agricultural waste: A case study of rice husk, Journal of Hazardous Materials, vol. 162, 312320.

C. J. Cruz-Olivares, Pérez-Alonso, C. Barrera-Díazb, G.López, P. Balderas-Hernándezb (2010), Inside the removal of lead(II) from aqueous solutions by De-Oiled Allspice Husk in batch and continuous processes. Journal of Hazardous Materials, vol. 6, pp. 535-545.

A. Demirbas (2000), Biomass resources for energy and chemical industry, Energy Edu. Sci.Technol. Vol. 5, pp. 2145.

M. Akhtara, S. Iqbalb, A. Kausarb, M. I. Bhangera, and M. A. Shaheen (2010), Colloids and Surfaces B: Biointerfaces Colloids and Surfaces B: Biointerfaces vol. 75, pp. 149155.

L. Armesto, A. Bahillo, K. Veijonen, A. Cabanillas, J. Otero (2002), Combustion behaviour of rice husk in a bubbling fluidised bed, Biomass Bioenerg, vol. 23, pp. 171-179.

S. Chen, B. Mulgrew, and P. M. Grant (1993), A clustering technique for digital communications channel equalization using radial basis function networks, IEEE Trans. on Neural Networks, vol. 4, pp. 570-578. 